\begin{tabular}{ll|l} 
Case Reports in & \begin{tabular}{l} 
Case Rep Gastroenterol 2016;10:781-786 \\
\cline { 2 - 3 } Gastroenterology
\end{tabular} & $\begin{array}{l}\text { DOI: 10.1159/000453657 } 2016 \text { The Author(s) } \\
\text { Published online: December 20, 2016 }\end{array}$ \\
& $\begin{array}{l}\text { Published by S. Karger AG, Basel } \\
\text { www.karger.com/crg }\end{array}$ \\
\cline { 2 - 3 } & $\begin{array}{l}\text { This article is licensed under the Creative Commons Attribution-NonCommercial } 4.0 \\
\text { International License (CC BY-NC) (http://www.karger.com/Services/OpenAccessLicense). } \\
\text { Usage and distribution for commercial purposes requires written permission. }\end{array}$
\end{tabular}

\title{
When Diarrhea Can Become Deadly: Legionnaires' Disease Complicated by Bowel Obstruction
}

\author{
Wesley Prichard Laurel Fick \\ Internal Medicine Faculty Department of Internal Medicine, St. Vincent Hospital, \\ Indianapolis, IN, USA
}

\section{Keywords}

Legionnaires' disease $\cdot$ Legionella $\cdot$ Bowel obstruction - Extrapulmonary Legionella

\begin{abstract}
Legionnaires' disease may present with a broad spectrum of illnesses and nonspecific extrapulmonary symptoms including diarrhea. To our knowledge, bowel obstruction has not been reported as a manifestation of Legionella. We present a unique case of Legionnaires' disease contributing to a small bowel obstruction.

(C) 2016 The Author(s)

Published by S. Karger AG, Basel
\end{abstract}

\section{Introduction}

Legionella pneumophila is a gram-negative bacillus which can cause atypical pneumonia in human hosts. The pathogen was first discovered in 1976 during an epidemic in Philadelphia among American Legion members, dubbing "Legionnaires' disease" [1-3]. There are many species of Legionella, but L. pneumophila is thought to cause more severe disease than the more common bacteria contributing to community-acquired pneumonia [2]. An intracellular and facultative pathogen, this bacterium lives within amoebae as a parasite and freely replicates within host macrophages which gives it the ability to survive the harsh environment and allows dissemination throughout the host [1-3]. Incubation time is 2-10 days for 
development of the pneumonic form. An estimated 25,000-100,000 persons are affected annually in the United States with this dangerous bacterium [4].

Infection with Legionella can be acquired by inhalation or aspiration of a contaminated water source including freshwater ponds and creeks, cooling towers, air conditioning systems, water fountains, respiratory-therapy equipment, and humidifiers - explaining both the community-acquired and nosocomial routes of transmission [2, 3]. Patient risk factors for contraction include smoking, alcohol use, chronic lung disease, end-stage renal disease, diabetes, malignancy, and immunosuppression (i.e. HIV/AIDS) [2, 3, 5]. Community-acquired Legionella patients typically have extrapulmonary manifestations initially and seek medical care much later following initial infection [6]. With delayed or inappropriate antibiotic use against Legionella, mortality has been reported to be around $60-70 \%$, but appropriate and rapid initiation of treatment decreases mortality to 10-20\% [7]. A urinary antigen test for L. pneumophila serogroup 1, which accounts for $90 \%$ of Legionella infections, has a sensitivity of $70 \%$ and a specificity of $100 \%$ [1]. Treatment with macrolides and fluoroquinolones is considered the first-line therapy for this bacterium [5].

Legionnaires' disease may begin with a broad spectrum of illnesses and nonspecific symptoms: fever, nonproductive cough, malaise, myalgia, anorexia, and headache. This constellation of symptoms can ultimately progress into respiratory and multi-organ failure [1, 8]. The extrapulmonary symptoms include neurologic changes, rhabdomyolysis, acute renal failure, electrolyte abnormalities, and various gastrointestinal manifestations [1, 2, 8, 9]. Multiple gastrointestinal symptoms from Legionella have been reported, including nausea, vomiting, elevated transaminases, secretory diarrhea (20-40\%), peritonitis, and even hemorrhage secondary to stress ulcers $[2,3,9]$. To our knowledge, this is the first reported case of bowel obstruction attributed to Legionella infection.

\section{Case Presentation}

A 67-year-old female with osteoporosis, hypothyroidism, and a remote abdominal hysterectomy presented to the emergency department with a chief complaint of 2 days of vomiting, watery diarrhea, confusion, lethargy, and high fever. Her system review was negative for respiratory or other abdominal complaints. Her medications consisted of levothyroxine and vitamin D with calcium supplements. Her social history was benign: she was a nonsmoker, nondrinker, and lived independently with her husband. On initial evaluation in the emergency department, she was hemodynamically stable (heart rate 97, blood pressure $163 / 76$ ), but febrile at $103^{\circ} \mathrm{F}$ and mildly tachypneic. Her physical examination demonstrated dry mucous membranes and diminished breath sounds at the left base of her lungs but was otherwise nonfocal - including a benign abdominal examination (soft, nontender, nondistended, normal bowel sounds). Her laboratory examinations demonstrated a moderate leukocytosis $(14,000 \mathrm{~K} / \mathrm{cumm})$ with $9 \%$ bands, elevated creatinine $(1.28 \mathrm{mg} / \mathrm{dL}$, baseline $0.8 \mathrm{mg} / \mathrm{dL}$ ) and BUN (22 mg/dL), lactate $3.74 \mathrm{mmol} / \mathrm{L}$, creatinine phosphokinase 15,445 U/L, hyperglycemia $249 \mathrm{mg} / \mathrm{dL}$, and elevated transaminases (ALT $91 \mathrm{U} / \mathrm{L}$, AST $170 \mathrm{U} / \mathrm{L}$, alkaline phosphatase $137 \mathrm{U} / \mathrm{L}$, total bilirubin $2.0 \mathrm{mg} / \mathrm{dL}$ with direct bilirubin $1.2 \mathrm{mg} / \mathrm{dL}$ ) with negative lipase $(9 \mathrm{U} / \mathrm{L})$ and albumin $3.0 \mathrm{gm} / \mathrm{dL}$. Urinalysis was significant for occult blood, protein of $100 \mathrm{mg} / \mathrm{dL}$, and urine ketones.

She was admitted for sepsis, dehydration, and rhabdomyolysis, all from presumed viral gastroenteritis. A chest X-ray (Fig. 1) revealed a questionable left lower lobe pulmonary opacity. After a right upper quadrant ultrasound demonstrated no significant hepatobiliary 
pathology, she underwent a computerized tomography (CT) of the abdomen and pelvis. The CT failed to pinpoint an etiology for her abdominal symptoms but confirmed a dense left lower lobe pulmonary infiltrate. Community-acquired pneumonia antibiotic coverage was initiated with azithromycin and piperacillin/tazobactam (the latter for possible aspiration with her confusion), and she was aggressively hydrated with normal saline. Hepatitis panel, TSH (1.77 UIU/mL), and hemoglobin A1c (5.7\%) were unremarkable. After 2 days on antibiotics with persistent fever and gastrointestinal symptoms, urine Legionella antigen was ordered and subsequently positive on day 3 of admission. Her antibiotics were changed to levofloxacin upon detection, but her nausea and vomiting acutely worsened along with severe abdominal distension. An abdominal X-ray (Fig. 2) demonstrated multiple dilated small bowel loops consistent with intestinal obstruction. A repeat CT of the abdomen and pelvis (Fig. 3) for further characterization confirmed a high-grade partial small bowel obstruction with a transition point in the distal ileum. She clinically improved with conservative management of her intestinal obstruction with nasogastric suction and intravenous fluid resuscitation while completing a course of antibiotics for L. pneumophila infection.

\section{Discussion}

The most common risk factors for the development of intestinal obstruction include previous abdominal surgery, neoplasms, hernias, electrolyte abnormalities, and medications [10]. While our patient had a remote history of hysterectomy, other identifiable risk factors causing her distension (including opioid medications) were not present in her care. A normal abdominal CT 3 days before the obstruction makes it unlikely that an anatomical defect was contributory. These findings lead us to believe that her legionellosis was primarily responsible for the development of this potentially fatal complication. As this complication has not previously been reported, the exact mechanism is unknown; however, we hypothesize that this may be directly attributable to specific systemic responses observed in Legionella infection. The host's cell-mediated immune response becomes activated when the bacterium invades macrophages for replication, thus initiating an overwhelming immune cascade triggered by its lipopolysaccharide, lipid A, component on its outside membrane [11]. Lipid A directly stimulates tumor necrosis factor alpha (TNF $\alpha$ ) production, which causes massive cytokine release and is primarily responsible for chloride secretion and subsequent development of diarrhea and intestinal inflammation [1,11-14]. We hypothesize that our patient's TNF $\alpha$ response directly caused massive gut inflammation and edema leading to hypoperfusion and subsequent intestinal obstruction. It is important that clinicians be aware of this complication of Legionella infection, especially in patients with a history of previous abdominal surgery.

\section{Statement of Ethics}

Approval for the use of this case was obtained by the patient and the St. Vincent Institutional Review Board. 


\section{Case Reports in \\ Gastroenterology}

(C) 2016 The Author(s). Published by S. Karger AG, Basel www.karger.com/crg

Prichard and Fick: When Diarrhea Can Become Deadly: Legionnaires' Disease Complicated by Bowel Obstruction

\section{Disclosure Statement}

The authors have no conflicts of interest to disclose.

\section{References}

1 Winn WC Jr: Legionella; in Baron S (ed): Medical Microbiology, ed 4. Galveston, University of Texas Medical Branch at Galveston, 1996, chapt 40. Available from:

http://www.ncbi.nlm.nih.gov/books/NBK7619/.

2 Stout JE, Yu VL: Legionellosis. N Engl J Med 1997;337:682-687.

3 Dahdouh M, Grantham C, Kay S: Atypical presentation of legionnaire's disease: a case report and review. New York Med J 2007. http://newyorkmedicaljournal.org/articles/atypical-presentation-oflegionnaires-disease/.

4 Steinert M, Hentschel U, Hacker J: Legionella pneumophila: an aquatic microbe goes astray. FEMS Microbiol Rev 2002;26:149-162.

5 Calza L, Briganti E, Casolari S, Manfredi R, et al: Legionnaires' disease associated with macular rash: two cases. Acta Derm Venereol 2005;85:342-344.

-6 Pedro-Botet ML, Sabria-Leal M, Haro M, Rubio C, et al: Nosocomial and community-acquired Legionella pneumonia: clinical comparative analysis. Eur Respir J 1995;8:1929-1933.

7 Kassha K, Abuanza I, Hadi SA, Hilton R: Severe Legionnaires disease complicated by multi-organ dysfunction in previously healthy patient: a case report. Cases J 2009;2:9151.

-8 Vergis E, Akbas E, Yu VL: Legionella as a cause of severe pneumonia. Semin Respir Crit Care Med 2000;21:295-304.

-9 Van Riemsdijk-van Overbeeke I, Van den Berg B: Severe Legionaire's disease requiring intensive care treatment. Neth J Med 1996;49:196-201.

10 Jackson P, Raiji M: Evaluation and management of intestinal obstruction. Am Fam Physician 2011;83:159-165.

11 Bishop R: The lipid A palmitoyltransferase PagP: molecular mechanisms and role in bacterial pathogenesis. Mol Microbiol 2005;57:900-912.

12 Cramer M: Legionnaires disease: a case study. Am J Crit Care 2003;12:234-238.

-13 Hofmann A, Beaulieu Y, Bernard F, Rico P: Fulminant legionellosis in two patients treated with infliximab for Crohn's disease: case series and literature review. Can J Gastroenterol 2009;23:829-833.

$\$ 14$ Reisinger EC, Fritzsche C, Krause R, Krejs GJ: Diarrhea caused by primarily non-gastrointestinal infections. Nat Clin Pract Gastroenterol Hepatol 2005;2:216-222. 


\section{Case Reports in Gastroenterology}

\begin{tabular}{l|l}
\hline Case Rep Gastroenterol 2016:10:781-786 \\
\hline DOI: 10.1159/000453657 & $\begin{array}{l}\text { @ 2016 The Author(s). Published by S. Karger AG, Basel } \\
\text { www.karger.com/crg }\end{array}$ \\
\hline
\end{tabular}

Prichard and Fick: When Diarrhea Can Become Deadly: Legionnaires' Disease Complicated by Bowel Obstruction

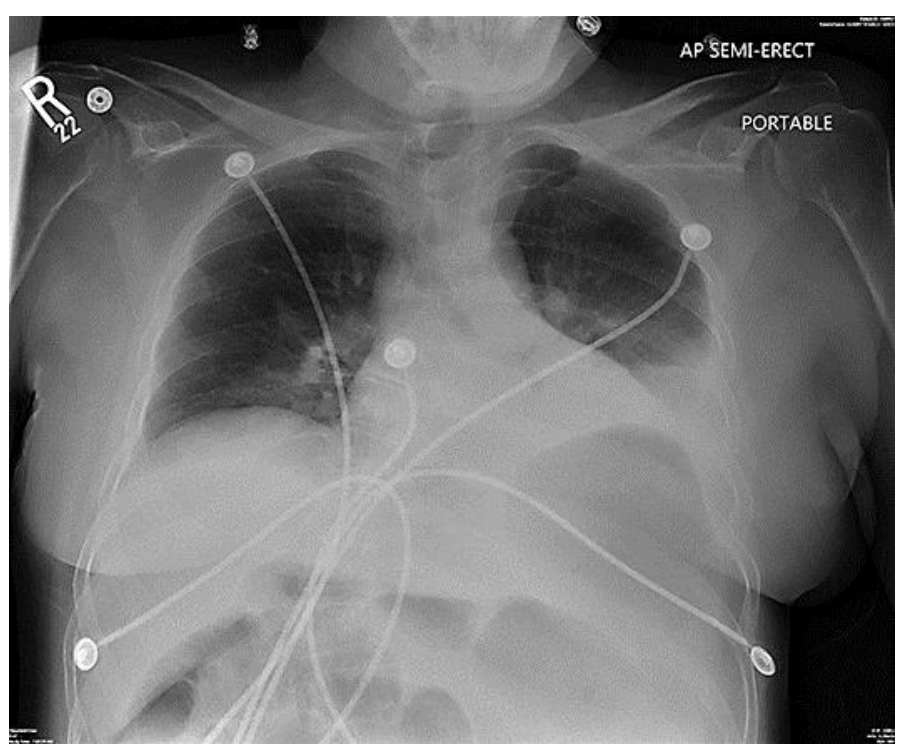

Fig. 1. Chest X-ray with left base opacity.

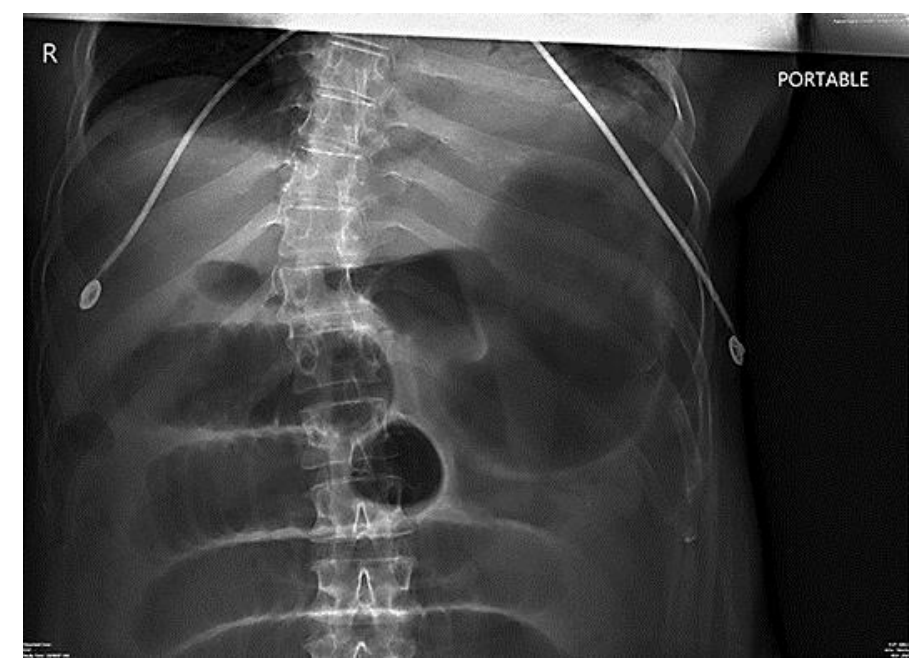

Fig. 2. Abdominal X-ray demonstrating obstruction. 


\begin{tabular}{ll|l} 
Case Reports in & \begin{tabular}{l} 
Case Rep Gastroenterol 2016;10:781-786 \\
\cline { 2 - 3 }
\end{tabular} & $\begin{array}{l}\text { DOI: } 10.1159 / 000453657 \\
\text { www.karger.com/crg }\end{array}$ \\
\hline $\begin{array}{l}\text { Prichard and Fick: When Diarrhea Can Become Deadly: Legionnaires' Disease } \\
\text { Complicated by Bowel Obstruction }\end{array}$
\end{tabular}

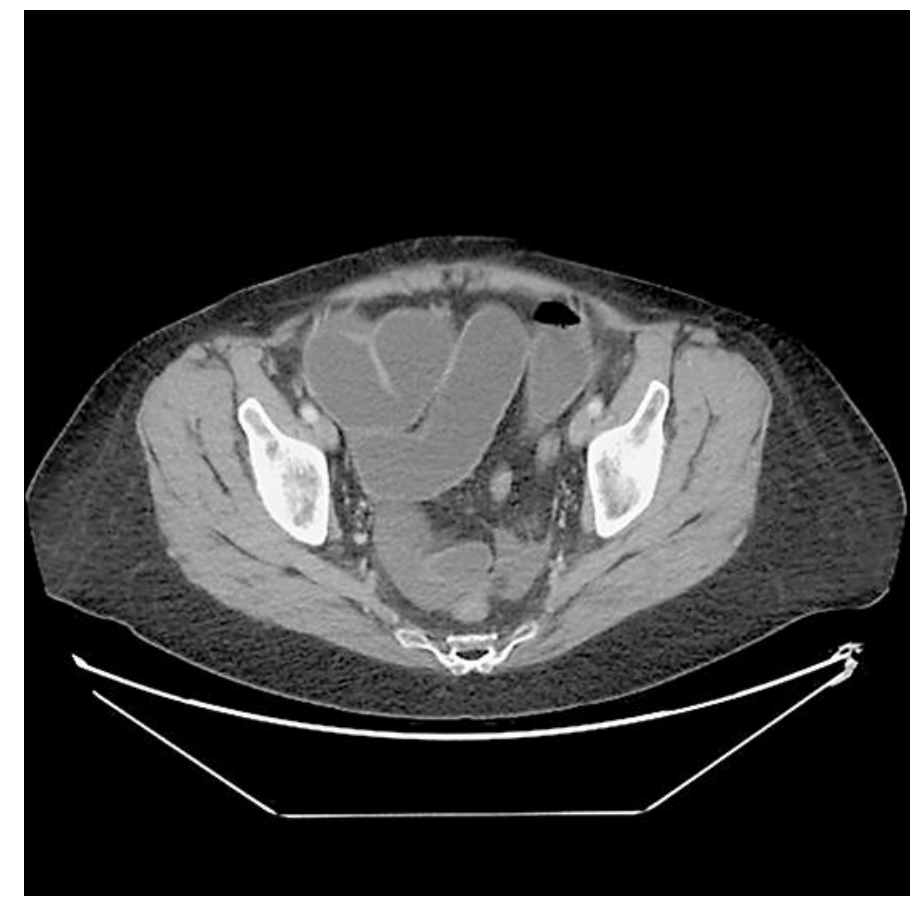

Fig. 3. Abdominal/pelvic CT of small bowel obstruction with transition point. 